\title{
Geodynamic and structural factors of porphyritic objects localization in Sikhote-Alin
}

\author{
Viktor Nevstruyev ${ }^{1 *}$ and Olga Kozlova ${ }^{1}$ \\ ${ }^{1}$ Institute of Tectonics and Geophysics, Far Eastern Branch of the Russian Academy of Sciences, \\ Khabarovsk, Russia.
}

\begin{abstract}
Ore bearing porphyritic systems of Sikhote-Alin form linear zones in Cretaceous volcanic belt. They are limited to zones of tectonic disturbances at Moho depths of 19-25 mi (30-40 km). Pacific slab lies at around 340 miles $(548 \mathrm{~km})$ below the volcanic belt, which matches the slab depth of porphyritic deposits formation belts in the Andes and Indonesia-Tonga region. Formation of porphyry copper systems is linked to the processes of metalliferous fluids intrusion at slab destruction areas near asthenosphere. Keywords: Sikhote-Alin, porphyritic intrusions, gold-copper mineralization, fluids, slab.
\end{abstract}

Porphyritic deposits are one of the most important world sources of copper. They possess significant and unique reserves of recoverable elements, including molybdenum, rhenium, precious and some other metals. Many issues concerning petrochemistry and deposit formation geodynamic control are still open to debate. Variety of tectonic and structural positions, petrochemical characteristics of primary magma, formation depth and scope of mineralization, as well as other parameters, result in a wide diversity of deposit models. At the same time, many of the characteristics are typical of porphyritic systems.

Majority of researchers agrees that porphyritic deposits are located in distribution areas of igneous rocks influenced by the processes in subduction zones. I and S-type porphyritic intrusions are considered ore bearing, but only some of them actually bear ore. Objects limited to continental margin volcanic belts containing magnetite igneous rocks are the most prospective. Some of them are accompanied by secondary quartzite distribution fields, distinguished by the fullness of manifestation of their facies [1], or spatial cositing of porphyry-copper and acid-sulphate mineralization, as it is at one of the largest gold deposits, Ladolam [2]. Detailed examination of S-type granitoids [3] showed that they form various groups under various conditions. As the result, we suggest distinguishing two subtypes, S1 and S2, which, while having similar chemical composition, form in different time and under different geodynamical conditions, and often contain intrusive contacts. The ore bearing subtype is $\mathrm{S} 2$, which is characterized by having higher partial pressure and fugacity of $\mathrm{H}_{2} \mathrm{O}, \mathrm{CO}_{2}$, and $\mathrm{HF}$ in fluids.

According to [4], porphyritic deposit formation is heavily influenced by magma enrichment by water and metals in the lower crust, sulphur oxidation in the molten mass, effective metal transfer by hydrothermal fluid released from magma, and ore localization

Corresponding author: nevstruevvg@mail.ru 
processes in the crust. It is important to mention that discovering these factors requires considerable amount of research, which is not always possible to give unique interpretation to.

The analysis of spaciotemporal location of porphyritic deposits in the Andes was conducted based on the plate tectonics model [5]. According to the data, the most important factors for porphyritic deposit formation in the Andes are the age (25 mln years), insignificant incidence angle of slab subduction $\left(10-15^{\circ}\right)$, relatively fast plate convergence (around $10 \mathrm{~cm} /$ year), distance from subduction trench (around $2000 \mathrm{~km}$ ), and aseismicity of subduction volcanic belts.

Reconstructing plate tectonics of the Andes based on the data [5], S. Timmermans [6] came to the conclusion that slab melting point and, therefore, belt aseismicity depends on the distance between the slab and the mantle, rather than speed and angle of slab immersion. The location of slab in relation to the mantle is a determining factor of ore bearing intrusion formation.

Based on the data [5] for the Andes belt, with the incidence angle of $10-15^{\circ}$ of subducting oceanic plate, slab immersion depth in the distribution area of porphyritic mineralization at $2000 \mathrm{~km}$ from the trench is $535 \mathrm{~km}$. At this depth the subducting oceanic plate begins to flatten out and disintegrate. We assume that with different slab incidence angle this number would change. The distance from the Western Pacific subduction area to the porphyritic intrusion belt of Sikhote-Alin is around $900 \mathrm{~km}$. With slab incidence angle of around $40^{\circ}$, according to the tomography profile [7], slab immersion depth there is 548 $\mathrm{km}$. For Marian type, with the average slab incidence angle of $80^{\circ}$, we see this depth in $150-200 \mathrm{~km}$ from the trench, which completely corresponds to empirical data [8, 9]. According to the analysis of ore deposits and slab depth in mineralization areas [8, table 1], there are no porphyritic objects below 600 and above $500 \mathrm{~km}$ deep, except for the Porgera deposit, where the older slab, supposedly, is topped off by the newer.

There are 3 porphyritic gold-copper deposits in Sikhote-Alin (Malmyzh and Gurskoye deposits in Khabarovsk Krai and Lazurnoye in Primorsky Krai, all undergoing exploration works), also, there are 91 occurrences and 34 secondary quartzite fields with alumstone facies, which are often connected to porphyry gold-copper mineralization (see fig.). All are limited to magnetite volcanic rocks [1].

In the southern part of the region they form a line in north-south direction, leaning towards the faults on eastern and western borders of Zhuravlevka terrane. In the northern part of the region, potential ore bearing objects form a line in east-west direction, along with a set of objects leaning towards the selvedge of the asthenospheric elevation. Deep structure models lead us to a conclusion that ore bearing structures are connected to mantle diapirism [10]. 


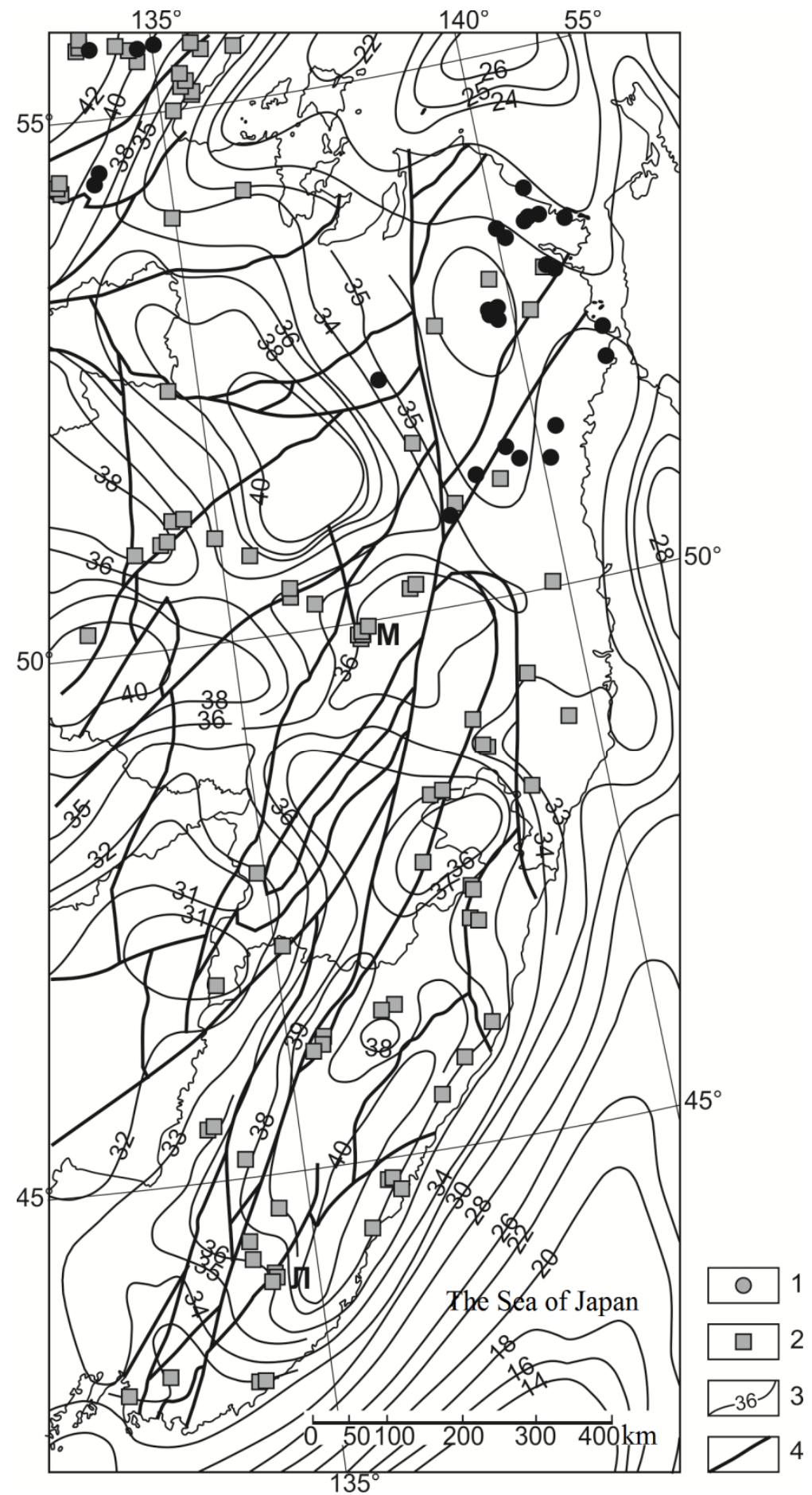

Plan of porphyritic gold-copper objects in Sikhote-Alin and Moho depths.

1 - secondary quartzite fields with alumstone facies; 2 - porphyritic gold-copper objects (deposits: Л - Lazurnoye, M - Malmyzh); 3 - contour lines of Moho depths; 4 - deep faults 
From petrological characteristics of igneous complexes in the eastern Sikhote-Alin volcanic belt [11] we can see that intrusive complexes of I and $\mathrm{S}$ types are limited to distribution fields in early Cretaceous island arc system (Kema terrane). Metal bearing objects are located close to regional fault area, forming northeastern trending linear zones. In the latitude of $48-51^{\circ}$ we can see a transversal strip of contiguous porphyritic goldcopper northeastern trending occurrences, which is probably connected to igneous rocks genesis in slab window area.

Results of geophysical data analysis show that metal bearing objects are limited to Moho depths of $35-40 \mathrm{~km}$. At this depth the upper crust begins to melt, accompanied by slab dehydration and asthenosphere fluids upwelling.

Malmyzh porphyritic gold-copper system is located in the western part of Zhuravlevka terrane near the central Sikhote-Alin fault [12]. High levels of lithosphere fragmentation and decompaction in mineralization distribution regions probably lead to dislocation of numerous metal bearing thermal springs and formation of porphyritic bodies. Rocks containing the deposits belong to ultra-aluminous intrusions of the late Cretaceous period and diorite and granodiorite containing minor intrusions. Majority of ore bodies are controlled by northeastern trending faults.

Lazurnoye deposit, which is the most petrochemically studied, is located near the southern part of Zhuravlevka terrane, between Sikhote-Alin and Furmanov deep faults [13]. Distribution of porphyritic intrusions, including the ore bearing ones, is connected to the Berezovsk fault area, which contains a voluminous northeastern trending minor intrusion belt. The intrusion has two phases characterized by their porphyritic outlook. Rocks of the second phase have deep mantle roots and are related to protolithic melting under conditions of high fluid level [13].

Authors of the summary on Sikhote-Alin intrusions [11] distinguish two stages of Stype granitoid formation: Hauterivian-Aptian orogenic stage and Late Albian, during which high volumes of calci-alkalic magnesian granitoids (S and I types) intruded fault systems. Dislocation of Isanagi plate in west-north-west direction during Cenomanian-Maastrichtian age resulted in frontal subduction of the Paleo-Pacific plate, which also influenced the formation of large amounts of plateau ingimbrinites and their intrusive counterparts from Itype acid magmatic melting. Slab disturbance and asthenosphere influence on subcontinental lithosphere resulted in lamproite and fayalite rhyolite invasion, gabbro and Atype alkaline granite intrusions.

To this day, forecasting of new ore regions was based on studying direct evidence of mineralization. Deep structure was seldom factored in it. The consistent patterns of ore bearing regions location in relation to irregularities in lithosphere are shown for gold deposits [14]. As for porphyritic gold-copper objects in the south of Far East, these factors are not yet studied well enough.

The listed sources tell us about the distinct connection between porphyritic gold-copper mineralization and subduction processes. First of all, $\mathbf{S}$ and I-type porphyritic intrusive complexes of Sikhote-Alin passed several stages of formation, but only some of them bear gold-copper mineralization, which is also noted for other regions as well [3 et al.]. The most important factor, in our opinion, is the nature of deep fluids that rise to higher levels of crust and lead to substance melting and, as the result, the formation of porphyritic intrusions.

Potential mineralization of slab magma retinue is based on the composition of its source: rocks from the basaltic layer of oceanic lithosphere, which passes this specialization to new liquids while melting (e.g. slab magma), capable of transferring "ore burden" to large distances and manifest its potential mineralization within the continental crust [15, $16]$. 
The early stage of formation of these types of intrusion begins with influx of fluids to dehydrated slab. Pyritic and gold-silver mineralization happens at this stage, often in the same space. This results in large and superlarge deposits like Ladolam [2].

The next stage is connected to the influx of deep fluids from asthenosphere and decaying slab in the phase of its initial destruction at the depth of 500-600 km. These fluids have drastically high levels of heavy element contents. They are transferred through the same channels (deep faults) that were the leaders of dehydration fluids [4]. As the result, we can see spatial cositing of intrusions of different stages. It is worth mentioning that not all fluids have high element burden that leads to deposit formation. This may result in interference of deep ore bearing intrusions with blank intrusions of the first stage and vice versa. Combining ore bearing fluids of two stages of porphyritic objects may lead to formation of large and unique polyformational deposits.

Predictive evaluation and localization of search areas, given their deep structure based on geophysical data, as well as geochemical and petrochemical research in order to discover sources of ore bearing fluids, may significantly reduce expenses during the early stages of searching.

This research is conducted as a part of Fundamental research program of Far East Division, RAS. Project 18-2-015 "Porphyritic gold-copper mineralization of Far East: indicators of geodynamical framework, ore bearing magmatism and mineralogical and geochemical features of ore-magmatic systems in relation to the issues of forecasting, search, valuation and management plans for deposits of this type."

\section{References}

1. L.F. Mishin, N.V. Berdniko, Ores and metals. 3, 14-24 (2010).

2. Müller D., Groves D. I. Potassic Igneous Rocks and Associated Gold-Copper Mineralization. (Berlin : Springer, 2016).

3. A.I. Gusev, Mod. High Technologies 3, pp 72-76 (2014).

4. Wilkinson, J. J. Nature science. 6(11), 917-925 (2013). http://doi.org/10.1038/ngeo1940

5. Butterworth, N., Steinberg, D., Müller, R. D., Williams, S., Merdith, A. S., \& Hardy, S. Tectonics. 35 (12), 2847-2862 (2016).

6. Timmermans S. Master thesis Faculty of Geosciences Utrecht University.- 36 p. (2017) https://dspace.library.uu.nl/handle/1874/352926

7. Bourova E., Yoshizawa K.,. Yomogida K. Physics of the Earth and Planetary Interiors. 183 (1-2), 20-32 (2010). DOI: 10.1016/j.pepi.2010.06.007

8. Garwin S., Hall R. and Watanabe Y. Society of Economic Geologists, Inc. Ec. Geol. 100th Anniversary Volume. 891-930 (2005).

9. Hall, R. and Spakman, W. Earth Planet. Sci. Lett. 201, 321-336 (2002). DOI: 10.1016/S0012-821X(02)00705-7

10. Deep structure and metallogeny of East Asia // Vladivostok. Dalnauka (2010).

11. A. V. Grebennikov, A. I. Khanchuk, V.G. Gonevchuk, S.V. Kovalenko, Lithos. 261, 250-261 (2016).

12. A.F. Chitalin, A.A. Yefimov, K.I. Voskresenky, E.K. Ignatyev, A.G. Kolesnikov, Mineral resources of Russia. 3, 65-69 (2013).

13. V.G. Sakhno, B.I. Gvozdev, P.P. Safronov, F.I. Rostovsky, L.S. Tsurikova. Minerageny problems of Russia GS RAS, Moscow: 301-324 (2012).

14. E.G. Ivolga. Ores and metals. 1, 14-25 (2013).

15. C.V. Efremov, A.M. Spiridonov, N.A. Goryachev. Mod. Dir. of Geoch. Dev. Ottisk, 87-88 (2017).

16. Huber C.O., Bachmann, J.-L., Dufek J. and Parmigiani A. Geochem. Geophys. Geosyst. 13, 8, 1-18 (2012). doi:10.1029/2012GC004042. 